\title{
PENGARUH MOTIVASI KERJA DAN DISIPLIN DIRI TERHADAP KEPUASAN DAN KINERJA KARYAWAN KANTOR KABUPATEN AINARO TIMOR LESTE
}

\author{
Sebastiao Costa Rangel Sousa Simoes ${ }^{1}$ \\ Gde Riana ${ }^{2}$ \\ Made Subudi ${ }^{3}$ \\ 1Program Magister Manajemen Pasca Sarjana Universitas Udayana \\ 2,3 Fakultas Ekonomi dan Bisnis, Universitas Udayana, Bali, Indonesia \\ Email: simoes.bastian@yahoo.com
}

\begin{abstract}
ABSTRAK
Kinerja karyawan merupakan hasil kerja karyawan dalam menjalankan tugas sesuai dengan tanggung jawab yang dibebankan. Motivasi dan disiplin diri, diyakini akan mempengaruhui kepuasan dan prestasi kinerja. Penelitian ini bertujuan untuk mengetahui pengaruh motivasi dan disiplin diri terhadap kepuasan kerja dan kinerja karyawan. Penelitian ini dilakukan dengan mengambil sampel 50 responden. Data dikumpulkan dengan mengunakan kuesioner berupa daftar pernyataan. Selanjutnya data yang telah terkumpul dianalisis dengan menggunakan analisi jalur (Path Analysis). Hasil analisis menunjukkan bahwa motivasi berpengaruh positif signifikan terhadap kepuasan kerja dan kinerja karyawan. Disiplin diri berpengaruh positip signifikan terhadap kepuasan kerja dan kinerja karyawan. Dan kepuasan kerja berpengaruh positip signifikan terhadap kinerja karyawan,
\end{abstract}

Kata Kunci: Motivasi Kerja, Disiplin Kerja, Kepuasan Kerja, Kinerja Pegawai

\begin{abstract}
Employee performance is the result of work of employees in carrying out their duties in accordance with the responsibilities assigned. Motivation and self-discipline, is believed to be influenced on satisfaction and performance excellence. This study aims to determine the effect of motivation and self-discipline to job satisfaction and employee performance. This study was conducted by taking of 50 respondents as a sample. Data were collected by using a questionnaire. Furthermore, the data that has been collected analyzed with path analysis. The analysis showed that the significant positive effect of motivation on job satisfaction and employee performance. Self -discipline is a significant positive effect on job satisfaction and employee performance. and job satisfaction significantly positive effect on employee performance.
\end{abstract}

Keywords: Motivation, Self-Discipline, Satisfactions and Employees Performance. 


\section{PENDAHULUAN}

Faktor-faktor yang mempengaruhi preatasi kerja pegawai diantaranya adalah motivasi kerja, disiplin kerja, dan kecerdasan emosional. Faktor motivasi kerja dan disiplin kerja merupakan variabel yang diteriliti dalam penelitian ini. Motivasi adalah perubahan energi dalam diri seseorang yang ditandai dengan munculnya (feeling) dan didahului dengan tanggapan terhadap adanya tujuan. Faktor utama yang dapat mempengaruhi motivasi kerja adalah disiplin diri. Disiplin adalah sikap mental yang tercermin dalam perbuatan atau tingkah laku perorangan, kelompok atau masyarakat berupa ketaatan (Obedience) terhadap peraturan atau ketentuan yang ditetapkan atau etik, norma, dan kaidah yang berlaku dalam masyarakat tertentu

\section{KAJIAN TEORI}

\section{Kinerja}

Kinerja karyawan secara umum merupakan hasil yang dicapai oleh karyawan dalam bekerja yang berlaku untuk suatu pekerjaan tertentu. Robins (Harrison:2000). Menurut (Lecky-Thomson, 2002) merupakan kesuksesan seseorang di dalam melaksanakan suatu pekerjaan dan kinerja tersebut pada dasarnya adalah hasil kerja seorang karyawan selama periode tertentu. Sedangkan menurut Dessler (2000) memberikan pengertian yang lain tentang kinerja yaitu merupakan perbandingan antara hasil kerja yang secara nyata dengan standar yang ditetapkan. Mathis dan Jackson (2002,p.78) kinerja pada dasarnya adalah apa yang dikerjakan dan yang tidak dikerjakan oleh karyawan. Kinerja dipengaruhi oleh faktor intrinsik dan faktor ektrinsik, menurut Lawson (2005). Indikator pengukuran kinerja menurut Kretner (2001), terdiri dari kualitas hasil kerja, 
kuantitas hasil kerja, ketepatan waktu penyelesaian pekerjaan, efektivitas hasil kerja, dan kemandirian.

\section{Disiplin Kerja}

Disiplin merupakan suatu perilaku yang taat dan patuh pada peraturan, etik, norma serta kaidah yang berlaku. Disiplin kerja merupakan penggunaan beberapa bentuk hukuman atau sanksi jika seseorang menyimpang dari peraturan, namun tidak semua ketentuan disiplin berbentuk hukuman (Niti Semito,2001). Disiplin bukan berarti hanya mematuhi peraturan kantor, datang tepat waktu, atu menyelesaikan pekerjaan tepat waktu, tapi lebih jauh lagi adalah kesadaran untuk melakukan segala sesuatu dengan target, menjaganya agar tetap berada pada jalurnya dan tetap sejalan dengan visi dan misi organisasi atau kantor dimana kita bekerja. Pendapat yang sama dikatakan oleh Discenza dan Smith (2000), Irmin (2004), Sinungan (2005), Rivai (2008), Glascoe (2000), Menurut Newstroom (2001), terdapat lima jenis bentuk sanksi dan hukuman yang diambil bila terjadi suatu pelanggaran guba penegakan disiplin, yaitu: (1) teguran lisan oleh pimpinan, (2) teguran tertulis dengan catatan dalam arsip, (3) penskorsan dari pekerjaan selama satu sampai tiga hari atau tiga minggu lebih lama, dan (4) pemberhentian dengan alasan. Penjatuhan hukuman disiplin dimaksudkan untuk memperbaiki dan mendidik anggota karyawan yang melakukan pelanggaran.

Indikator-indikator disiplin diri yaitu, meliputi: (1) ketaatan atau kepatuhan terhadap peraturan di kantor, (2) kesadaran untuk melaksanakan tugas sesuai dengan pedoman yang ada, (3) tanggung jawab terhadap pekerjaan, dan (4) kejujuran dalam bekerja. 


\section{Motivasi Kerja}

Menurut Berelson dan Steiner (2005), motivasi merupakan suatu motif adalah kondisi terdalam yang dapat memberikan energy untuk mengerakkan (Motivasi) dan menggarahkan perilaku terhadap tujuan (Motive is an inner state that is an energizer to move hence motivation and that directs behavior toward goal). Hal yang sama dikatakan pula oleh Tabrani Rusyan (2004), Djamarah (2000). Sedangkan menurut Siegel dan Newstron (2002) motivasi adalah proses dimana perilaku dimulai dan diarahkan (motivation as the process by which behavior is initiated and directed). Indrantoro (2007) mengemukakan bahwa motivasi adalah kekuatan terpendam yang mendorong seseorang untuk berperilaku secara khusus. Indikator pengukuran motivasi kerja didasarkan pada Maslow dalam Siagian (2007), yang terdiri dari: kebutuhan fisiologis, kebutuhan rasa aman, kebutuhan sosial, kebutuhan harga diri, dan kebutuhan aktualisasi diri.

\section{Kepuasan Kerja}

Mathis and Jackson (2000) mengemukakan, "Job satisfaction is a positive emotional state resulting one's job experience." (Kepuasan kerja merupakan pernyataan emosional yang positive yang merupakan hasil evaluasi dan pengalaman kerja), sedangkan menurut Davis dan John (2007) mengartikan kepuasan kerja adalah seperangkat perasaan pegawai tentang menyenangkan atau tidaknya pekerjaan mereka. Sementara itu, menurut Davis dan John (2007) mengartikan kepuasan kerja adalah seperangkat perasaan pegawai tentang menyenangkan atau tidaknya pekerjaan mereka. Locke \& Adiko Winnetouw 
(2008), mengemukakan bahwa kepuasan kerja adalah apa yang dirasakan oleh seseorang pekerjaan atas mereka, hal ini menunjukkan bahwa sejauh mana individu merasakan hasil yang sesuai dari mereka harapkan dari suatu pekerjaan sehingga nantinya akan secara langsung mempengaruhi kinerja karyawan. Pengukuran kepuasan kerja didasarkan pada indikator sifat pekerjaan, supervisi, upah, kesempatan promosi dan hubungkan promosi dengan rekan kerja.

\section{Kerangka Konseptual dan Hipotesis Penelitian}

Kerangka konsep dan hipotesis penelitian mengenai pengaruh motivasi kerja, disiplin kerja terhadap kepuasan kerja dan kinerja pegawai, ditunjukkan seperti dalam Gambar 1, dibawah ini.

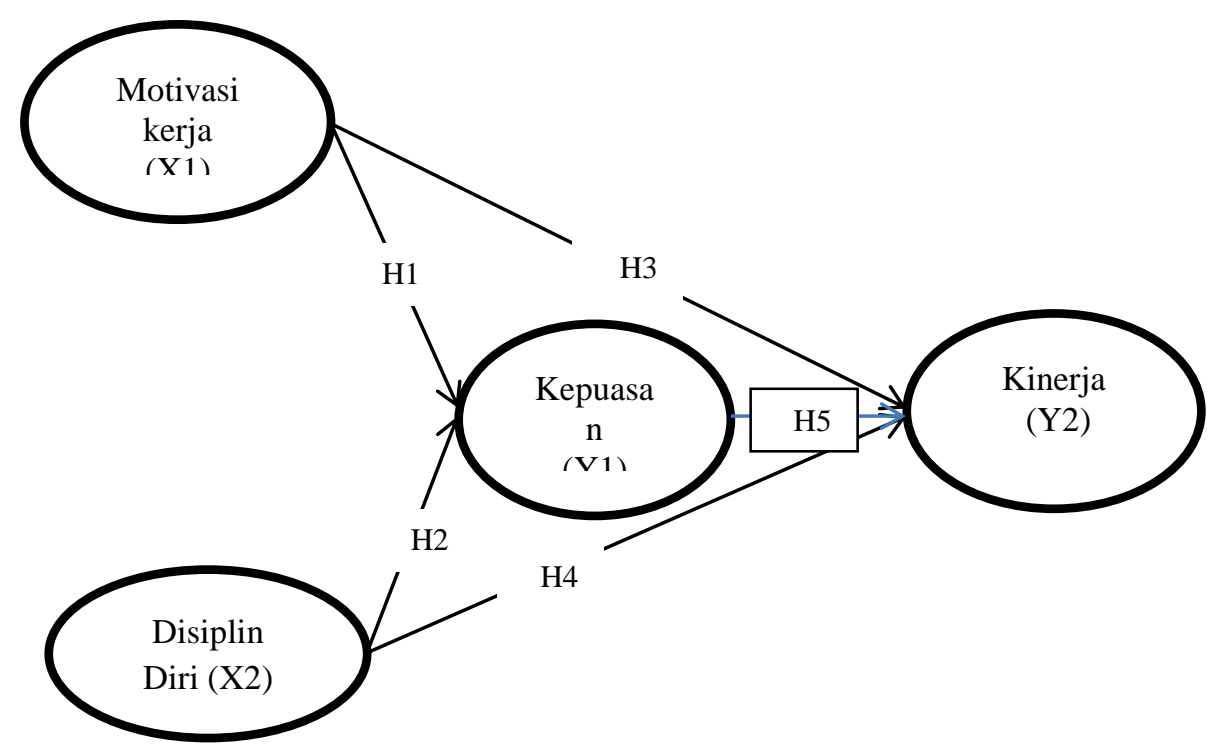

Gambar 1.

Kerangka Konsep hubungan Antara Motivasi Kerja, Disiplin Kerja, Kepuasan Kerja, dan Kinerja karyawan 
Berdasarkan kerangka konsep tersebut di atas, maka susunan hipotesis penelitian ini adalah :

H1 : Motivasi berpengaruh positif signifikan terhadap kepuasan kerja

H2 : Disiplin Diri berpengaruh positif signifikan terhadap kepuasan kerja

H3 : Motivasi berpengaruh positif signifikan terhadap Kinerja Karyawan

H4 : Disiplin Diri berpengaruh positif signifikan terhadap Kepuasan kerja

H5 : Disiplin diri berpengaruh positif signifikan terhadap kinerja karyawan

\section{METODE PENELITIAN}

Penelitian dilakukan di Kantor Kabupaten Ainaro, dengan melibatkan seluruh populasi yang ada yaitu sebanyak 50 orang pegawai tidak termasuk Bupati dan Wakil Bupati. Analisis penelitian dilakukan melalui Analisis Jalur Path Analysis), yaitu menentukan pengaruh variabel eksogen terhadap variabel emdogen, yang dalam hal ini variabel motivasi kerja (X1) dan disiplin kerja(X2) adalah merupakan variabel eksogen, sedangkan kepuasan kerja (Y1) dan kinerja (Y2) adalah merupakan variabel endogen, dengan formula sebagai berikut:

$$
\begin{aligned}
& \text { Sub Structure 1: } \mathrm{Y} 1=\beta 1 \mathrm{X} 1+\beta 2 \mathrm{X} 2+\mathrm{el} \\
& \text { Sub Structure 2: } \mathrm{Y} 2=\beta 3 \mathrm{X} 1+\beta 4 \mathrm{X} 2+\beta 5 \mathrm{Y} 1+\mathrm{e} 2
\end{aligned}
$$

\section{HASIL DAN PEMBAHASAN}

Dari hasil uji klasik, yang terdiri dari uji normalisasi, uji multikolinearitas, dan uji heteroskedastisitas, menunjukkan bawa data hasil penelitian layak untuk dilanjutkan sebagai data pendukung analisis Path, dimana data berdistribusi secara normal, bebas dari multikolinearitas, dan tidak mengandung heteroskedastisitas. Hasil pengujian pengenai pengaruh masing-masing variabel eksogen terhadap endogen, ditunjukkan sebagai berikut: 
1. Pengaruh Motivasi Terhadap Kepuasan

Hasil analisis menujukkan ada pengaruh positif signifikan variabel Motivasi terhadap Kepuasan dengan koefisien standardize beta sebesar 0,374 dengan signifikansi uji t sebesar 0,009. Hal ini menunjukkan bahwa semakin tinggi motivasi maka kepuasan kerja di Kantor Administrasi Kabupaten Ainaro Timor - Leste juga akan semakin tinggi. Koeffisien motivasi yang sudah distandarisasi ditunjukkan dengan nilai beta sebesar 0,374 artinya 37,4 persen perubahan Kepuasan disebabkan oleh Motivasi.

2. Pengaruh Disiplin Diri Terhadap Kepuasan Kerja

Hipotesisi kedua adalah hipotesis yang menyebutkan bahwa ada pengaruh positif yang signifikan secara langsung variabel Disiplin diri terhadap Kepuasan kerja. Hasil analisis menujukkan ada pengaruh positif signifikan variabel Disiplin diri terhadap Kepuasan dengan koefisien standardize beta sebesar 0,471 dengan signifikansi uji t sebesar 0,001. Hal ini menunjukkan bahwa semakin tinggi Disiplin diri maka kepuasan kerja di Kantor Administrasi Kabupaten Ainaro Timor - Leste juga akan semakin tinggi. Koeffisien Disiplin diri yang sudah distandarisasi ditunjukkan dengan nilai beta sebesar 0,471 artinya 47,1 persen perubahan Kepuasan disebabkan oleh Disiplin diri.

3. Pengaruh Motivasi terhadap Kinerja Karyawan Hipotesisi ketiga adalah hipotesis yang menyebutkan bahwa ada pengaruh positif yang signifikan secara langsung variabel Motivasi terhadap Prestasi Kerja. Hasil analisis menujukkan ada pengaruh positif signifikan variabel 
Motivasi terhadap Prestasi Kerja dengan koefisien standardize beta sebesar 0,296 dengan signifikansi uji t sebesar 0,037. Hal ini menunjukkan bahwa semakin tinggi Motivasi maka Prestasi Kerja kerja di Kantor Administrasi Kabupaten Ainaro Timor - Leste juga akan semakin tinggi. Koefisien Motivasi yang sudah distandarisasi ditunjukkan dengan nilai beta sebesar 0,296 artinya 29,6 persen perubahan Prestasi Kerja disebabkan oleh Motivasi.

4. Pengaruh Disiplin diri terhadap Kinerja Karyawan

Hipotesisi keempat adalah hipotesis yang menyebutkan bahwa ada pengaruh positif yang signifikan secara langsung variabel Disiplin diri terhadap Prestasi Kerja. Hasil analisis menujukkan ada pengaruh positif signifikan variabel Disiplin diri terhadap Prestasi Kerja dengan koefisien standardize beta sebesar 0,328 dengan signifikansi uji t sebesar 0,027. Hal ini menunjukkan bahwa semakin tinggi Disiplin diri maka Prestasi Kerja kerja di Kantor Administrasi Kabupaten Ainaro Timor - Leste juga akan semakin tinggi. Koefisien Disiplin diri yang sudah distandarisasi ditunjukkan dengan nilai beta sebesar 0,328 artinya 32,8 persen perubahan Prestasi Kerja disebabkan oleh Disiplin diri.

5. Pengaruh Kepuasan terhadap Kinerja Karyawan Hipotesisi kelima adalah hipotesis yang menyebutkan bahwa ada pengaruh positif yang signifikan secara langsung variabel Kepuasan terhadap Prestasi Kerja. Hasil analisis menujukkan ada pengaruh positif signifikan variabel Kepuasan terhadap Prestasi Kerja dengan koefisien standardize 
beta sebesar 0,280 dengan signifikansi uji $\mathrm{t}$ sebesar 0,046. Hal ini menunjukkan bahwa semakin tinggi Kepuasan maka Prestasi Kerja kerja di Kantor Administrasi Kabupaten Ainaro Timor - Leste juga akan semakin tinggi. Koefisien Kepuasan yang sudah distandarisasi ditunjukkan dengan nilai beta sebesar 0,280 artinya 28 persen perubahan Prestasi Kerja disebabkan oleh Kepuasan.

\section{SIMPULAN DAN SARAN}

\section{Simpulan}

Berdasarkan pembahasan di atas, maka dapat disimpulkan sebagai berikut.

1. Motivasi kerja berpengaruh positif signifikan terhadap kepuasan kerja karyawan. Hal ini berarti bahwa semakin baik pemberian motivasi kepada para karyawan maka, kepuasan kerja karyawan di kantor kabupaten Ainaro Timor-Leste akan semakin meningkat.

2. Disiplin diri berpengaruh positif signifikan terhadap kepuasan kerja karyawan. Kondisi ini mengindikasikan bahwa semakin baik tingkat disiplin diri karyawan, maka kepuasan kaerja di Kantor Kabupaten Ainaro Timor-Leste akan semakin meningkat.

3. Motivasi kerja berpengaruh positif signifikan terhadap kinerja karyawan. Maknanya bahwa motivasi kerja yang semakin baik akan meingkatkan kinerja yang mampu dicapai karyawan di Kantor Kabupaten Ainaro TimorLeste. 
4. Disiplin diri berpengaruh positif signifikan terhadap kinerja karyawan. Hal ini dapat dijelaskan bahwa disiplin diri yang semakin baik mampu meningkatkan kinerja karyawan di Kantor Kabupaten Ainaro Timor Leste.

5. Kepuasan kerja berpengaruh positif signifikan terhadap kinerja karyawan. Hal ini berarti semakin baik kepuasan kerja karyawan, maka kinerja karyawan di kantor kabupaten Ainaro Timor Leste akan semakin meningkat.

\section{Saran}

1. Kinerja di kantor Administrasi Kabupaten Ainaro Timor - Leste, perlu ditingkatkan terutama dalam hal Pekerjaan harus sesuai dengan standar,Pekerjaan harus mencapai target, kemampuan dalam menyelesaikan pekerjaandan sikap kerjasama karyawan dalam menyelesaikan pekerjaan.

2. Motivasi harus diperkuat terutama dalam hal; Komunikasi dengan pemimpin dengan bawahan, dukungan pemimpin terhadap bawahan dalam menyelesaikan pekerjaan dan dorongan pemimpin untuk memberikan contoh yang baik dan mempengaruhi bawahannya.

\section{REFERENSI}

Adhiatma, 2008. Behavior on Organization " Diunduh tanggal 13January 2013 dari http://www.petra.ac.id/ puslit/journals/dir.php?DepartmentID=MAN

Anwar Prabu. 2009. Manajemen Sumber Daya Manusia Perusahaan. Bandung : PT. Remaja Rosdakarya 
Amstrong, Michael, 2002, A Handbook of Human Resources Management Practice, 10th Edition,London: Kogan Page Limited Pentoville Read.

Bigge L. Morris dan Hunt 1980. Murice Psychological Fundation of education (New York: Harper and Bubu Row Publisher. p.30

Dipboye, Robert, L., Smith, C. S., Howell, W. C., 1994, Understanding Industrial and Organizational Behavior, USA: Winston Inc.

Davis dan Newstroom, 1996. Prilaku dan Organisasi, terjemahan Agus Dharma (Jakarta: Erlangga, 1996. p.87

De Cenzo dan robbins, 1998. Human Resources Management ( New York: Jhon Wiley and Sons, Inc., 1998) p.113

Edy Sutrisno,2009, Manajemen Sumber Daya Manusia, Penerbit Kencana Prenada media Group Jakararta

French L. Wendell. 1998. Human Resources Management. New Jersy; Houghton Mifflinn Company. P.112

Juhro, R Muchammad. 1978. Jurnal dan Praktek 2. Jakarta: Kanisius.

Hariandja, M. T. E. 2005. Manajemen Sumber Daya Manusia Cetakan ketiga. Jakarta: PT. Grasindo

Malayu S.P. Hasibuan, 2005, Manajemen Sumber Daya Manusia, Penerbit Bumi Aksara Jakararta

Hasibuan, M. S. P. 2007. Manajemen Sumber Daya Manusia. Jakarta: Bumi Aksara.

Hasibuan, Malayu. 2010. Organisasi \& Motivasi. Jakarta: PT. Bumi Aksara

Handoko T Hari 2000, Manajemen Personalia Sumber Daya Manusia: BPFE

Handoko, T. Hani. 2001. Manajemen Personalia dan Sumber Daya Manusia. Yogyakarta : BPFE.

Hasibuan, Melayu.S.P. 2001. Manajemen Sumber Daya Manusia. Jakarta: PT Bumi Aksara.

Hariandja, Manhot Tua Efendi. 2002. Manajemen Sumber Daya Manusia. Jakarta: Gramedia Widiasarana Indonesia.

Henry Simamora, 2005, Manajemen Sumber Daya Manusia, Penerbit Andi, Yogyakarta.

Indrantoro,1987. Sri Suparyo 1987. Manajemen Proses Belajar Mengajar (Jakarta: Yayasan Pembinaan Keluarga UPN Veteran) P.60

Gomes, Faustino C., 2005, Manajemen Sumber Daya Manusia, Yogyakarta: Penerbit ANDI.

George, J. M. \& Jones, G. R., 2005, Essentials of Managing Organizational Behavior, 4th ed.,New Jersey: Upper Saddle River. 
Panggabean, Mutiara S, "Manajeman Sumber Daya Manusia", Ghalia Indonesia, Jakarta, 2002.

Prabu, A., Desember 2005, "Pengaruh Motivasi Terhadap Kepuasan Kerja Pegawai Badan Koordinasi Keluarga Berencana Nasional Kabupaten Muara Enim", Jurnal Manajemen \& Bisnis Sriwijaya, vol. 3, no. 6, hal. 125 .

Palm, T. 2008. Performance Assessment and Authentic Assessment: A Conceptual Analysis of the Literature

McClelland, Steers, 1988. Efektivitas Organisasi. Terjemahan Yamin, Magdalena, Pent. Jakarta: Erlangga. p.33

Marsden 2007. "Organization and Job Satisfaction” Diunduh tanggal 13January 2013 dari

http://www.petra.ac.id/ puslit/journals/dir.php?DepartmentID=MAN

Nawawi, Hadari. 2008. Manajemen Sumberdaya Manusia Untuk Bisnis Yang Kompetitif. Yogyakarta: Gajah Mada University Press.

Nolker,Helmut,1983.Pendidikan Kejuruan (Jakarta: PT Gramedia). P.30

Robert; dan Smith, 1994,'Perilaku Organisasi”, Buku 1, Edisi Kelima, Salemba Empat, Jakarta.

Ridwan E. 2008. Cara menggunakan analisis jalur (Path Analysis). Cetakan pertama Bandung; Alfabeta

Robbins, S. P., 2003, Perilaku Organisasi, Jakarta: PT. Indeks Kelompok Gramedia.

Robbins, S.P. 2010. Perilaku Organisasi. Edisi Bahasa Indonesia Jilid I dan II. Jakarta: Prinhalindo.

R.Wayne Pace Don F.Faules.2010.Komunikasi Organisasi Strategi Meningkatkan Kinerja

Singarimbun, Masri dan Sofian Effendi.2006. Metode Penelitian Survai. Jakarta: PT Pustaka LP3ES Indonesia.

Sutrisno, Edy. 2011. Manajemen Sumber Daya Manusia. Jakarta: Kencana.

Shende, S. S \& Malony, A. D. 2006. The Tau Parallel Performance System. International Journal of High Performance Computing Applications. Vol. 20.

Stavrinoudis, T. A. 2008. Applying S.W.O.T. Analysis Methodology in The Formulation of Propositions Aiming at a More Effective Operational Application of Timeshare In Greece. An International Multidisciplinary Journal Of Tourism. Vol. 3, No. 2, pp: 113-138.

Saydam, Gouzali, 2000, Manajemen Sumber Daya Manusia, Cetakan Kedua, Jakarta

Sutrisno, Edy. 2009. Manajemen Sumber Daya Manusia. Jakarta: Kencana. 
Stavrinoudis, T. A. 2008. Applying S.W.O.T. Analysis Methodology in The Formulation of Propositions Aiming at a More Effective Operational Application of Timeshare In Greece. An International Multidisciplinary Journal Of Tourism. Vol. 3, No. 2, pp: 113-138.

Shende, S. S \& Malony, A. D. 2006. The Tau Parallel Performance System. International Journal of High Performance Computing Applications. Vol. 20.

Sarwono dan Suhayati, 2010. Riset Akuntansi Menggunakan SPSS, Graha Ilmu, Bandung

Sinungan, 1997. Produktivitas apa da Bagaimana 9Jakarta: Bumi Aksara, 1997). p. 145

Soeprapto, 1996. Disiplin Nasional dan Etos Kerja di Indonesia (Jakarta: Citraluhur Tata mandiri), p 49

Mc.Clell Smith, , "Increasing Eml 74 2 Productivity, Job Satisfaction, and Organizational Commitme ospital and HealthServices Administration, Vol.41, No.2, pp.160-175

Slameto, 1991. Belajar dan factor-faktor yang mempengaruhinya, Jakarta: Bina Aksara P.1

Siegel Laurence dan Irving M, Lane, 1982. Personnel and Organizational Psychological ( USA: Richard D, Irwin Inc)

Steiner, dan Berelson dalam Wahjosumidjo 1992. Kepemimpinan dan Motivasi (Jakarta: Ghalia Indonesia) p.177.

Soetopo dan Soemanto,1986. Kepemimpinan dan Supervisi Pendidikan. Jakarta: bina Aksara p. $291-293$

Winardi, J, "Motivasi \& Pemotivasian Dalam Manajemen", Cetakan ketiga, PT RajaGrafindo Persada, Jakarta, 2004.

Wahyosumidjo, 1992. Kepemimpinan dan Motivasi, (Jakarta: Ghalia Indonesia P. 177

Wursanto 1985, Manajemen Sumber Daya Manusia, CV. Haji Masagung, Jakarta, 1994.

Yuli, Sri Budi Cantika. 2005. Manajemen Sumber Daya Manusia. Malang: UMM Press.

Arikunto, Suharsimi. 2002 Prosedur Penelitian Suatu Pendekatan Praktis, Penerbit Cipta, Jakarta

Cromin, J.J, Jr and J.A. taylor 1992 “ Marketing Service Quality : A Resxamation and Extension " Journal of Marketing, 56 ( july 1992 ) : h: 55-68

Fandy, Tjiptono 2002 Manajemen Jasa.Penerbit Andi, Yogyakarta.

Ghozali, Iman 2006. Aplikasi Analisis Multivariate Dengan Program SPSS Cetakan IV. Semarang : Badan Penerbit Universitas Diponegoro 
Sebastiao Costa Rangel Sousa Simoes, Gde Riana, dan Made Subudi. Pengaruh Motivasi...

Hinton, T/Schaeffer, W 2000 Fokus Kualitas pada pelanggan, Peberbit Helirary, Jakarta

Sugiyono, 2002, Metode Penelitian Bisnis, Cetakan keempat, Penerbit CV. Alfabeta, Bandung.

Sugiyono, 2007, Statistik Untuk Penelitian, Penerbit CV. Alfabeta, Bandung.

Wibowo, Arief, 2003. Pengantar Analisis Jalur ( Path Analysis ). Disampaikan oleh Lembaga Penelitian Universitas Airlangga, Surabaya 15-16 Juli 2003. 